\title{
Effects of Seed Source and Fertilization on Germination and Growth of Khaya senegalensis (Desr.) in Benue State, Nigeria
}

\author{
Kuje, Emmanuel Dauda ${ }^{1} \quad$ Agera, Stephen.Iorliam.Naishima ${ }^{2 *} \quad$ Amonum, Joseph. Igba $^{2}$ \\ 1.Department of Forestry, Wildlife \& Ecotourism, Nasarawa State University, Keffi-Nigeria \\ 2.Department of Forest Production \& Products, University of Agriculture Makurdi- Nigeria
}

\begin{abstract}
Khaya senegalensis (Desr.) A. Juss is one of the most economic forest tree species used for high quality furniture, building and construction purposes. It has high medicinal values. There is high demand for the species and the plantation production of the species is scarce. There is inadequate information on the right fertilizer type and amount needed to raise the tree species in nurseries and plantation. This study set out to investigate the effects of seed source on seed germination and effects of fertilizer types on the early growth of the tree species. $K$. senegalensis seeds were collected from three locations (progenies) in Benue State, namely: Vandeikya, Makurdi and Oju. The experiment was laid out in a $3 \times 4 \times 5$ factorial design. Treatments administered included: treatment A (topsoil and poultry manure), B (topsoil and cow dung), C (topsoil and NPK 15:15:15 fertilizer) and treatment D-topsoil only (control). The seeds were planted in plastic pots filled with $1 \mathrm{~kg}$ of topsoil and river sand at the Forestry Nursery of the Federal University of Agriculture, Makurdi.. Treatments were administered at five different levels of $5 \mathrm{~g}, 10 \mathrm{~g}, 15 \mathrm{~g}, 20 \mathrm{~g}$ and $25 \mathrm{~g}$ each of poultry manure, cow dung, mixture of cowdung and Poultry manure, NPK 15.15.15 inorganic fertilizers and top soil only (Control) Each treatment consisted of 20 experimental pots replicated three times. Germination was monitored at intervals of three (3) days. Treatments were applied after germination was observed. Seedling growth parameters measured included plant height, collar diameter, leaf number, leaf area, plant fresh weight and dry weight. Data collected was subjected to descriptive statistics and two-way ANOVA. Seed germination results differed significantly $(\mathrm{p}<0.05)$ among the three locations. The results showed seeds collected from Makurdi had the highest germination percentage (35.6\%). The results on fresh weight and dry weight showed that seedlings treated with cow dung in Makurdi and Poultry manure in Oju had the highest mean fresh weight $(30.8 \mathrm{~g})$ and dry weights $(9.5 \mathrm{~g})$. Results on leaf area showed seedlings treated with Poultry manure recorded the highest mean leaf area $\left(68.8 \mathrm{~cm}^{2}\right)$ in Makurdi. Poultry manure had the highest significant effects on the seedlings height growth. Seedlings treated with poultry manure yielded the overall best growth results.
\end{abstract}

Key words: Khaya. senegalensis, germination, growth, organic manure and NPK fertilizer.

DOI: $10.7176 / \mathrm{JBAH} / 9-4-05$

Publication date: February 28, 2019

\section{I.Introduction}

Khaya Senegalensis (Desr) A. Juss commonly known as African mahogany is a hardwood tree species which belongs to the Meliaceae family that grow up to $15-30 \mathrm{~m}$ in height and $1 \mathrm{~m}$ in diameter ${ }^{1}$. . The bark is dark grey to grey-brown while the heartwood is brown with a pink-red pigment made up of coarse interlocking grains. The bole of this species is usually straight with well-developed plank buttresses, thick, coarse, reddish-brown, and with bitter tastes ${ }^{2}$. The plant is characterized by leaves arranged in a spiral formation clustered at the end of branches. It is often planted by the roadsides for shade in countries of its natural range and also increasingly in tropical zones of other continents ${ }^{3}$.

Plantation establishment of Khaya senegalensis is scarcely extensive, this presents a business opportunity to foresters and prospective users of the species especially considering the economic potentials of this hard wood tree species. Young leaves contain fairly large quantities of digestible crude protein and are used as a fodder for cattle and camels, although they are not very palatable $\mathrm{r}^{1,4}$. Dried stem-bark is useful in treatment of dermal infection ${ }^{5}$ Consumption of K. senegalensis apart from decreasing the risk of breast cancer infection also helps to protect the skin against harmful ultra violet rays ${ }^{6}$.

.There is however, scantily documented information on the right amount of organic and inorganic fertilizer application in raising this tree species. Adequate soil fertility is essential for sustainable plant production. The high demand for Khaya senegalensis has been on ascendancy. The production capacity is low and therefore does not meet the ever growing demand for human use. To mitigate this problem, this research was initiated to assess effects of location (progeny) and fertilization on seed germination and early growth of Khaya senegalensis (Desr) seedlings.

\section{Materials and Methods}

The Study Area

This study was conducted at the Forestry Nursery of the Department of Forest Production and Products, University 
of Agriculture Makurdi, Benue State, Nigeria. Benue State lies between Longitude $8^{\circ} 21^{\prime}$ and $9^{\circ}$ E and Latitude $7^{\circ} 21^{\prime}$ and $8^{\circ} \mathrm{N}$ within the Southern Guinea Savanna ecological zone. The climate of the area is tropical sub-humid with high temperatures and high humidity. The maximum temperature is $35^{\circ} \mathrm{C}$ while the minimum temperature is $23{ }^{0} \mathrm{C}^{7}$. The climate is characterized by two distinct seasons namely; rainy and dry seasons with an annual rainfall of $1200 \mathrm{~mm}-1500 \mathrm{~mm}$. The vegetation of the area has been described as Southern guinea savanna. Benue State has boundaries to the south with Enugu and Cross River States, to the East with Taraba State to the North with Nasarawa State and West with Kogi State. The major occupations of the people include; farming, fishing, trading and hunting; the major tribes found are Tiv, Idoma and Igede.

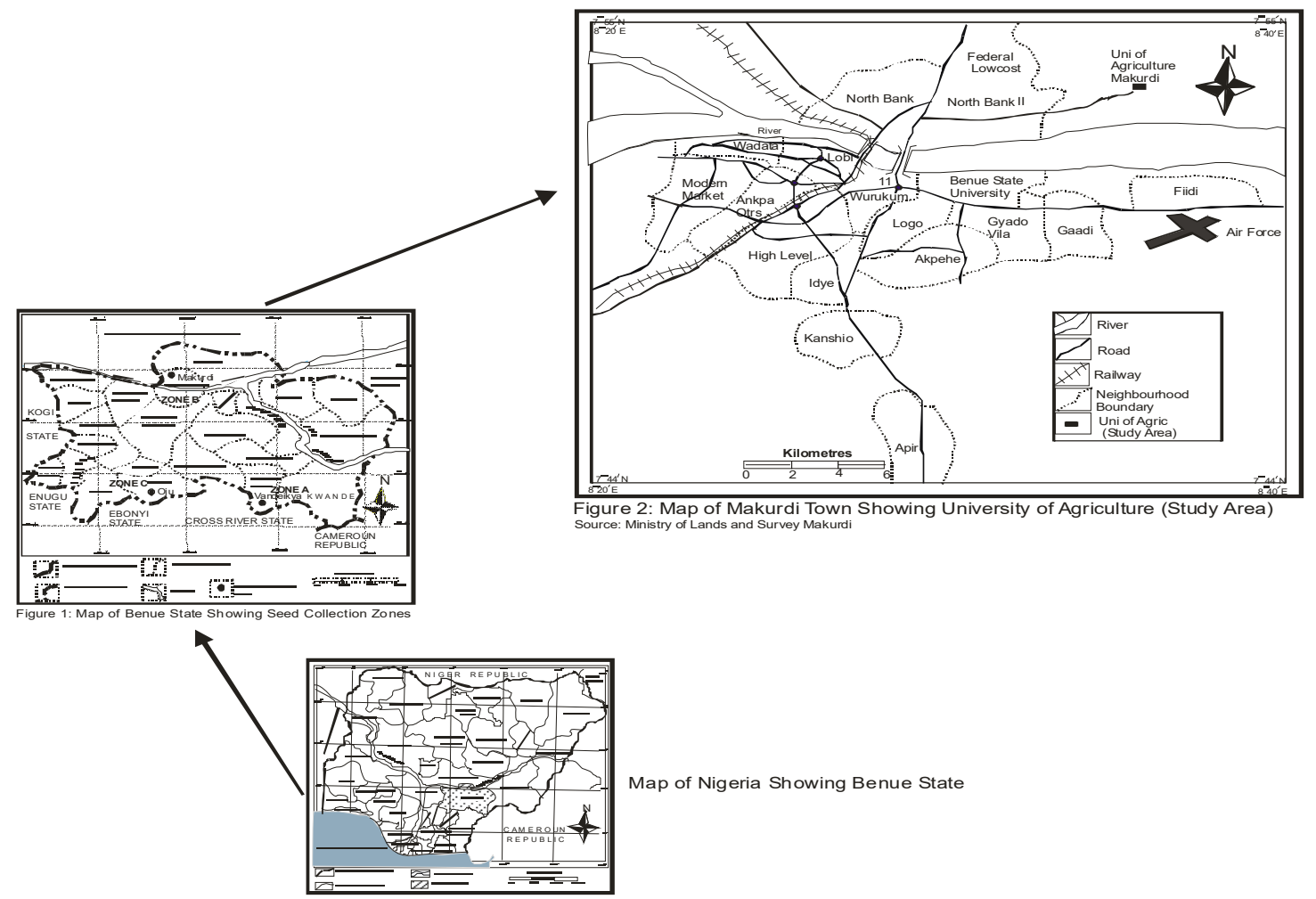

Figure 1: Map of Nigeria showing Benue State and the Study Area

\section{Experimental Design}

The experimental design for the research was a $3 \times 4 \times 5$ factorial design with four (4) treatments: treatment A (poultry manure), B (cow dung), C (NPK fertilizer 15:15:15) and treatment D (no fertilization which served as the control $)^{8}$. The experiment was conducted in plastic pots each containing $1 \mathrm{~kg}$ of topsoil. Treatments were applied at five different levels: level $1(5 \mathrm{~g})$ each of organic and inorganic fertilizer, level $2(10 \mathrm{~g})$, level $3(15 \mathrm{~g})$, level 4 $(20 \mathrm{~g})$ and level $5(25 \mathrm{~g})$ each of organic and inorganic fertilizer, respectively. Seeds used for the study were collected from three locations in Benue State namely: Vandeikya, Makurdi and Oju from mature mother trees of superior phenotypic traits.

Two seeds of Mahogany (K. senegalensis) were sown at an average depth of $2 \mathrm{~cm}$ in each plastic pot and later thinned to one stand per pot after germination ${ }^{9}$. It took the seeds between 10 to 14 days to germinate. Each treatment consisted of 20 experimental pots replicated three times for each treatment. One hundred and eighty seeds (180) from each zone were sown in plastic pots perforated at the base to facilitate drainage making a total of six hundred and thirty (630) seeds including the control. Treatments were applied two weeks after germination was assessed.

Topsoil used for this work was obtained from the Forestry Nursery, University of Agriculture, Makurdi while cow dung and poultry manure were collected at the Poultry and Livestock Farm, University of Agriculture Makurdi. Seedlings were subjected to the same watering regime (once daily) throughout the experimental period ${ }^{8}$.

\section{Data Collection}

Data on seeds germination from each zone was recorded until emergence ceased. Two seedlings were randomly selected from each level in each treatment and the parameters measured included: plant height, collar diameter, 
number of leaves and leaf area. Seedling fresh and dry weights were determined at the terminal stage of the research work. Seedling parameters such as plant height were measured from the collar region to the tip of the seedlings by using a meter rule. Collar diameter was measured using a veneer caliper. Numbers of leaves were determined by manually counting the number of leaves on the seedlings. Leaf area was measured by tracing leaves of seedling on a graduated graph sheet. Five seedlings from each treatment were selected and leaf area assessed fortnightly ${ }^{10}$. The fresh and dry weights of the seedlings were taken using an electronic weighing scale. The dry weights were taken after 48 hours of oven drying at a temperature of $60^{\circ} \mathrm{C}$. Three seedlings from each treatment were randomly selected and carefully removed from the growing medium to determine their mean dry weight $(\mathrm{g})^{11}$.

\section{Data Analysis}

Data collected on seed germination and growth were subjected to descriptive statistics such as percentages, mean and standard deviation and inferential statistics (two-way analysis of variance (ANOVA)) was adopted using the statistical package Minitab 17th Edition. Where significant differences occurred between the treatments means, the least significant difference (LSD) method was used to separate the means ${ }^{8,10,12}$.

\section{III.Results}

Effects of Seed source (Progeny) on Germination of Khaya senegalensis Seeds

The results on germination percentage on $K$. senegalensis seeds collected from different progenies are presented in Table 1. The result shows significant differences $(p<0.01)$ from the fourteenth day $\left(14^{\text {th }}\right)$ of seed germination to the twenty third day. On the $23^{\text {rd }}$ day after planting, seeds collected from Makurdi recorded the highest percentage germination $(35.80 \pm 0.20 \%)$. This was followed by seeds collected from Oju which had a percentage germination of $33.51 \pm 0.01 \%$ which was lower than that Makurdi on the $23^{\text {rd }}$ days after planting. Seeds from Vandeikya recorded the lowest percentage germination $(26.80 \pm 0.10 \%)$ of all seeds from the three locations.

Table 1: Germination Percentage on $K$. senegalensis Seed from three Locations in Benue State

\begin{tabular}{lllll}
\hline \multirow{2}{*}{$\begin{array}{c}\text { Growing Period } \\
\text { Days) }\end{array}$} & \multicolumn{3}{c}{ Germination Percentage of Progenies } & \multirow{2}{*}{ P-Value } \\
\cline { 2 - 4 } & VANDEIKYA & MAKURDI & OJU & \\
\hline 14 & $7.61 \pm 0.11^{\mathrm{c}}$ & $20.40 \pm 0.09^{\mathrm{a}}$ & $17.41 \pm 0.20^{\mathrm{b}}$ & $<0.01$ \\
17 & $12.18 \pm 0.11^{\mathrm{c}}$ & $25.65 \pm 0.05^{\mathrm{a}}$ & $23.56 \pm 0.06^{\mathrm{b}}$ & $<0.01$ \\
20 & $22.00 \pm 1.00^{\mathrm{c}}$ & $29.54 \pm 0.46^{\mathrm{a}}$ & $26.22 \pm 0.17^{\mathrm{b}}$ & $<0.01$ \\
23 & $26.80 \pm 0.10^{\mathrm{c}}$ & $35.80 \pm 0.20^{\mathrm{a}}$ & $33.51 \pm 0.01^{\mathrm{b}}$ & $<0.01$ \\
Mean & $17.15 \pm 0.27^{\mathrm{c}}$ & $27.84 \pm 0.20^{\mathrm{a}}$ & $25.17 \pm 0.07^{\mathrm{b}}$ & $<0.01$ \\
\hline
\end{tabular}

Means on the same row with different superscript are statistically significant $(\mathrm{p}<0.05)$

Effect of fertilizer type on the mean leaf area of Khaya senegalensis seedlings

Table 2 shows the effect of organic and inorganic fertilizer on the leaf area of $K$. senegalensis seedlings in the three progenies. The result revealed that poultry manure (TP), NPK 15:15:15 fertilizer (TF) and Control had no significant effect on the leaf area of Khya senegalensis seedlings while cow dung (TC) had significant ( $\mathrm{p}=0.04)$ effect on the leaf area of $K$. senegalensis seedlings among the progenies. Makurdi had the highest mean leaf area of $50.48 \pm 4.32 \mathrm{~cm}^{2}$ due to application of cow dung followed by poultry manure which had a mean leaf area of $48.22 \pm 5.51 \mathrm{~cm}^{2}$ in Oju while NPK 15:15:15 recorded a leaf area of $40.55 \pm 6.80 \mathrm{~cm}^{2}$. The least mean leaf area $\left(25.32 \pm 5.17 \mathrm{~cm}^{2}\right)$ was recorded in control from Vandiekya.

Table 2: Effect of Fertilizer Type on Leaf Area of $K$. senegalensis Seedling from the Three Progenies $\left(\mathrm{cm}^{2}\right)$

\begin{tabular}{lllll}
\hline Treatments & \multicolumn{3}{c}{ Leaf Area of Progenies by Treatment } & P-Value \\
\cline { 2 - 4 } & Vandeikya & Makurdi & Oju & \\
\hline TP & $38.73 \pm 6.12$ & $41.17 \pm 6.68$ & $48.22 \pm 5.51$ & $\mathbf{0 . 5 3}^{\text {ns }}$ \\
TF & $31.77 \pm 6.24$ & $38.95 \pm 6.35$ & $40.55 \pm 6.80$ & $\mathbf{0 . 6 0}^{\text {ns }}$ \\
TC & $32.10 \pm 5.85^{\mathrm{b}}$ & $50.48 \pm 4.32^{\mathrm{a}}$ & $39.97 \pm 5.44^{\mathrm{ab}}$ & $\mathbf{0 . 0 4}^{\text {ns }}$ \\
Control & $25.32 \pm 5.17$ & $32.83 \pm 4.46$ & $30.92 \pm 4.09$ & $\mathbf{0 . 5 0}^{\text {ns }}$ \\
\hline
\end{tabular}

Means on the same row with different superscript are statistically significant $(\mathrm{p}<0.05)$; $\mathrm{ns}=$ not significant.

Where: $\mathrm{TP}=$ Poultry manure; $\mathrm{TC}=\mathrm{Cow}$ dung and $\mathrm{TF}=\mathrm{NPK}$ fertilizer $(15: 15: 15)$

Effect of fertilizer type on the mean leaf count of Khaya senegalensis seedlings

Table 3 shows the effect of provenances and fertilization on the mean number of leaves of Khaya senegalensis seedlings. The result revealed that there were significant differences $(\mathrm{P}=0.05)$ between the progenies on the mean number of leaves of $K$. senegalensis seedlings. Seedlings from Oju seed stock significantly recorded the highest $(9.50 \pm 0.34)$ mean number of leaves followed by Makurdi which had a mean number of leaves of $9.33 \pm 0.32$ while Vandiekya had $8.54 \pm 0.21$ leaves which was lower than that of Makurdi and Oju. The least mean number of leaves $(6.22 \pm 0.23)$ was recorded from the control in Vandiekya. 
Table 3: Effects of Seed Source and fertilization on the mean number of leaves of Khaya senegalensis seedlings

\begin{tabular}{|c|c|c|c|}
\hline \multirow[t]{2}{*}{ Treatment } & \multicolumn{3}{|c|}{ Provenance } \\
\hline & Vandeikya & Makurdi & Oju \\
\hline Control & $6.22 \pm 0.23^{\mathrm{c}}$ & $8.26 \pm 0.37^{b}$ & $8.10 \pm 0.37^{b}$ \\
\hline $\mathrm{TC}$ & $8.52 \pm 0.26^{\mathrm{a}}$ & $9.33 \pm 0.32^{\mathrm{a}}$ & $8.78 \pm 0.29^{\mathrm{ab}}$ \\
\hline $\mathrm{TF}$ & $8.54 \pm 0.21^{\mathrm{a}}$ & $8.56 \pm 0.25^{\mathrm{ab}}$ & $9.50 \pm 0.34^{\mathrm{a}}$ \\
\hline $\mathrm{TP}$ & $7.57 \pm 0.25^{\mathrm{b}}$ & $8.20 \pm 0.30^{\mathrm{b}}$ & $7.91 \pm 0.30^{\mathrm{b}}$ \\
\hline P-Value & $<0.01$ & 0.02 & $<0.01$ \\
\hline
\end{tabular}

Means on the same column with different superscript are statistically significant $(\mathrm{p}<0.05)$, ns $=$ not significant.

Where: $\mathrm{TP}=$ Poultry manure; $\mathrm{TC}=\mathrm{Cow}$ dung and $\mathrm{TF}=\mathrm{NPK}$ fertilizer $(15: 15: 15)$

Comparative effect of organic and inorganic fertilizer application on the fresh weight of seedlings from different locations in Benue State

Figure 2 shows comparative effects of organic and inorganic fertilizer application on the Fresh Weight of $K$. senegalensis seedlings from the three zones in Benue state. The highest fresh weight $(30.8 \mathrm{~g})$ was recorded by application of cow-dung to $K$. senegalensis seedlings from Makurdi; followed by NPK fertilizer application $(30.6 \mathrm{~g})$ in Makurdi while Poultry manure application in zone $\mathrm{C}$ gave a fresh weight of $29.2 \mathrm{~g}$ which was lower than that of Makurdi. The least fresh weight $(16.0 \mathrm{~g})$ was obtained from the Control in Oju.

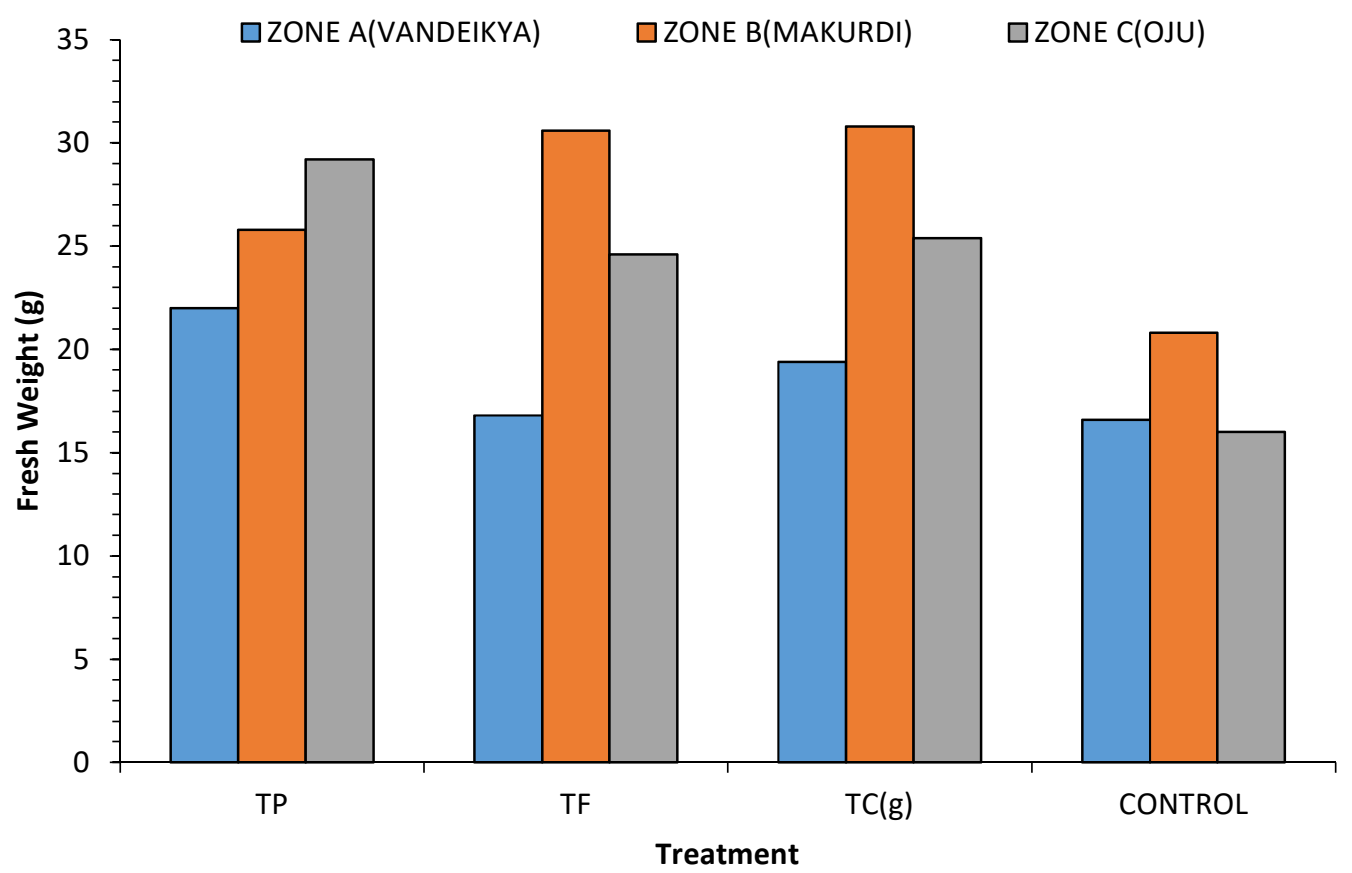

Figure 2: Comparative Effects of Organic and Inorganic Fertilizers on the Fresh Weight of $\mathrm{K}$. senegalensis Seedlings from Different Zones of Benue, Nigeria

Comparative Effects of Organic and Inorganic Fertilizer on the Dry Weight of $K$. senegalensis Seedlings from Different zones in Benue, Nigeria

Figure 3 indicates that the dry weight among the fertilizer treatments were as follows: poultry manure application recorded the highest mean dry weight of $9.5 \mathrm{~g}$ for $\mathrm{Oju}$, followed by a mean dry weight of $7.5 \mathrm{~g}$ for Makurdi while Vandeikya recorded a mean seedling dry weight of $6.9 \mathrm{~g}$. NPK fertilizer gave a mean dry weight of $8.5 \mathrm{~g}$ in Makurdi while Oju recorded a mean dry weight of $8.0 \mathrm{~g}$ whereas Vandeikya had the least mean dry weight of $4.7 \mathrm{~g}$. Seedlings applied cow dung had a mean dry weight of $9.1 \mathrm{~g}$ for seedlings in Oju while Makurdi recorded a dry weight of $8.0 \mathrm{~g}$ and 5.6g in Vandeikya Similarly, seedling dry weight from the control was $6.6 \mathrm{~g}$ in Makurdi This was followed by 
a mean seedling dry weight of $5.6 \mathrm{~g}$ in Oju whereas the least dry weight $(4.8 \mathrm{~g})$ was obtained for seedlings in Vandeikya.

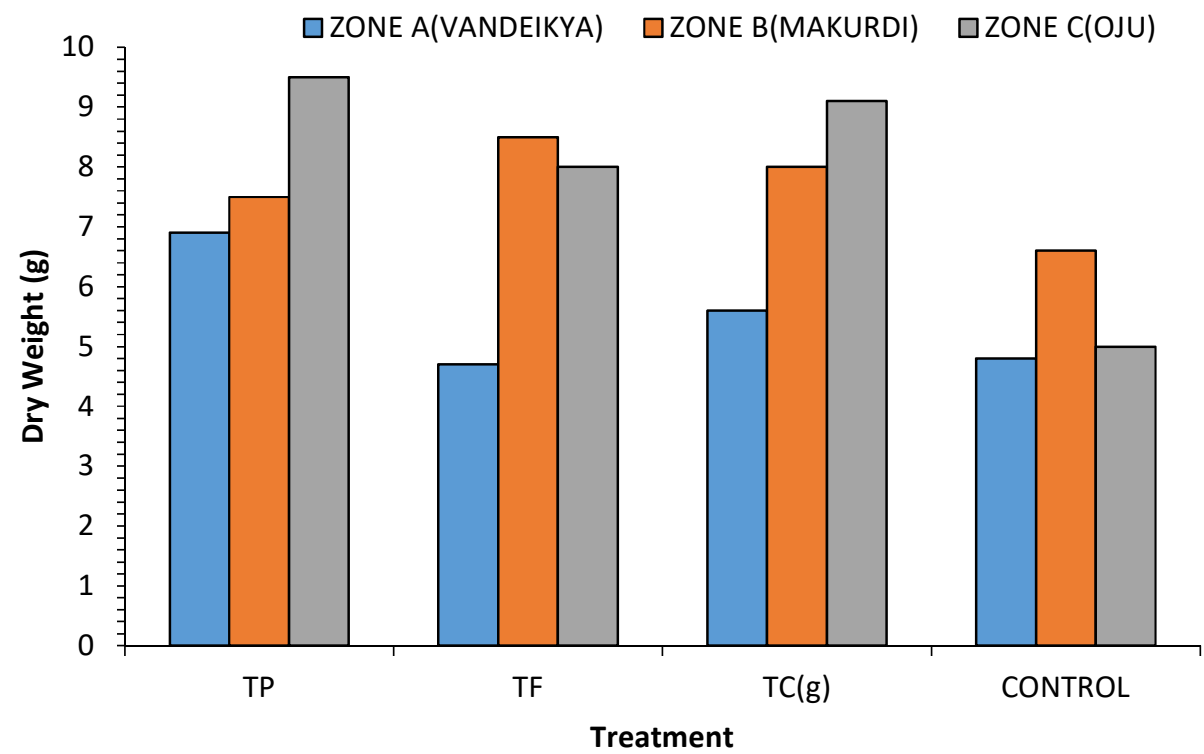

Figure 3: Comparative Effects of Organic and Inorganic Fertilizer on the Dry Weight of $K$. senegalensis Seedlings from Different zones in Benue, Nigeria

Effects of fertilizer type on the mean leaf count of $K$. senegalensis seedlings

Table 4 shows the effect of fertilizer type on the mean number of leaves of $K$. senegalensis seedlings. The result indicated that there were significant differences $(\mathrm{p}=0.05)$ among the fertilizer type on the mean number of leaves of $K$. senegalensis seedlings in the three zones. Poultry manure yielded the highest mean number of leaves $(9.50 \pm 0.34)$ in Oju followed by cow dung which had $9.33 \pm 0.32$ as mean number of leaves in Makurdi while NPK $15: 15: 15$ fertilizer application recorded $6.39 \pm 0.29$ as the mean number of leaves which was less than that of poultry manure, cow dung and the control.

Table 4: Effects of Fertilizer Type on the Mean Number of Leaves of $K$. senegalensis Seedlings

\begin{tabular}{llll}
\hline Treatment & \multicolumn{3}{l}{ Mean number of Leaves by treatment and location } \\
\cline { 2 - 4 } & \multicolumn{1}{l}{ Vandeikya } & Makurdi & Oju \\
\hline Control & $6.66 \pm 0.18^{\mathrm{b}}$ & $8.26 \pm 0.27^{\mathrm{ab}}$ & $8.10 \pm 0.21^{\mathrm{b}}$ \\
$\mathrm{TC}$ & $8.52 \pm 0.26^{\mathrm{a}}$ & $\mathbf{9 . 3 3} \pm \mathbf{0 . 3 2}$ & $8.78 \pm 0.29^{\mathrm{ab}}$ \\
$\mathrm{TF}$ & $\mathbf{6 . 3 9} \pm \mathbf{0 . 2 9}$ & $7.47 \pm 0.32^{\mathrm{b}}$ & $6.65 \pm 0.33^{\mathrm{c}}$ \\
$\mathrm{TP}$ & $8.54 \pm 0.21^{\mathrm{a}}$ & $8.56 \pm 0.25^{\mathrm{ab}}$ & $\mathbf{9 . 5 0} \pm \mathbf{0 . 3 4}$ \\
\multicolumn{1}{c}{$P$-Value } & $<0.01$ & $<0.01$ & $<0.01$ \\
\hline
\end{tabular}

Means in the same Column with different superscript are statistically significant $(\mathrm{p}<0.05)$, ns $=$ not significant. Where: $\mathrm{TP}=$ Poultry manure; $\mathrm{TC}=\mathrm{Cow}$ dung and $\mathrm{TF}=\mathrm{NPK}$ fertilizer $(15: 15: 15)$

Effect of Fertilizer type on the mean height of Khaya senegalensis seedlings

Table 5 shows the effect of fertilizer type on the mean height growth of $K$. senegalensis seedlings. The results showed significant differences $(\mathrm{P}<0.01)$ for all fertilizer types among the various locations (Vandeikya, Makurdi and Oju). For Vandeikyya, the application of cow dung and poultry manure had no significant difference on seedling height; also the control and NPK fertilizer (15:15:15) did not differ significantly in seedling height observed. In Makurdi, there was no significant difference between the treatments (Cow dung, NPK fertilizer and poultry manure) but seedling height varied significantly with the control $(\mathrm{P}<0.01)$. For Oju, seedling height varied significantly with the control, cow dung and NPK fertilizer while cow dung and poultry manure did not differ significantly in seedling height. Also between cow dung and NPK fertilizer treatment, no significant difference was observed in the mean height of Khaya senegalensis seedlings. 
Table 5: Effect of Fertilizer Type on Mean Height of $K$. senegalensis Seedlings

\begin{tabular}{|c|c|c|c|}
\hline \multirow[t]{2}{*}{ Treatment } & \multicolumn{3}{|c|}{ Mean height of seedlings in Zones (cm) } \\
\hline & Vandeikya & Makurdi & Oju \\
\hline Control & $13.07 \pm 0.63^{\mathrm{bc}}$ & $15.25 \pm 0.67^{b}$ & $14.05 \pm 0.60^{\mathrm{a}}$ \\
\hline $\mathrm{TC}$ & $14.40 \pm 0.37^{\mathrm{ab}}$ & $17.48 \pm 0.49^{\mathrm{a}}$ & $8.78 \pm 0.29^{b c}$ \\
\hline $\mathrm{TF}$ & $12.13 \pm 0.38^{\mathrm{c}}$ & $14.26 \pm 0.50^{b}$ & $7.91 \pm 0.30^{\mathrm{c}}$ \\
\hline $\mathrm{TP}$ & $14.52 \pm 0.37^{\mathrm{a}}$ & $17.44 \pm 0.47^{\mathrm{a}}$ & $9.50 \pm 0.34^{\mathrm{b}}$ \\
\hline P-Value & $<0.01$ & $<0.01$ & $<0.01$ \\
\hline
\end{tabular}

Means on the same column with different superscript are statistically significant $(\mathrm{p}<0.05)$, $\mathrm{ns}=$ not significant. Where: $\mathrm{TP}=$ Poultry manure; $\mathrm{TC}=\mathrm{Cow}$ dung and $\mathrm{TF}=\mathrm{NPK}$ fertilizer $(15: 15: 15)$

Effect of Fertilizer type on the mean collar diameter of Khaya senegalensis seedlings

Table 6 shows the effect of fertilizer type on the mean collar diameter of $K$. senegalensis seedlings. The results showed no significant variation in collar diameter $(\mathrm{P}=0.36)$ between the fertilizer types within Vandeikya. In Oju, there were significant differences $(\mathrm{P}<0.01)$ between the control, cow dung, poultry manure and NPK $(15: 15: 15)$ fertilizer but no significant difference between cow dung (TC) and poultry manure (TP); whereas in Oju, there were significant differences in collar diameter $(\mathrm{P}=0.04)$ between the fertilizer types.

Table 6: Effect of Fertilizer Type on Mean Collar Diameter of $K$. senegalensis Seedlings

\begin{tabular}{clll}
\hline Treatment & \multicolumn{3}{c}{ Mean Collar Diameter of seedlings by location $(\mathbf{m m})$} \\
\cline { 2 - 4 } & Vandeikya & Makurdi & Oju \\
\hline Control & $3.43 \pm 0.18^{\mathrm{a}}$ & $4.80 \pm 0.15^{\mathrm{a}}$ & $3.27 \pm 0.14^{\mathrm{b}}$ \\
TC & $3.42 \pm 0.10^{\mathrm{a}}$ & $3.82 \pm 0.10^{\mathrm{b}}$ & $4.01 \pm 0.24^{\mathrm{a}}$ \\
TF & $3.23 \pm 0.09^{\mathrm{a}}$ & $3.03 \pm 0.08^{\mathrm{c}}$ & $3.49 \pm 0.09^{\mathrm{b}}$ \\
TP & $3.47 \pm 0.10^{\mathrm{a}}$ & $3.69 \pm 0.09^{\mathrm{b}}$ & $3.85 \pm 0.10^{\mathrm{ab}}$ \\
$\boldsymbol{P}$-Value & $0.36^{n s}$ & $<0.01$ & 0.04 \\
\hline
\end{tabular}

Means on the same column with different superscript are statistically significant $(\mathrm{p}<0.05)$, ns $=$ not significant.

Where: $\mathrm{TP}=$ Poultry dung manure; $\mathrm{TC}=\mathrm{Cow}$ dung manure and $\mathrm{TF}=\mathrm{NPK}$ fertilizer $(15: 15: 15)$

\section{IV.Discussion}

Seed germination in K. senegalensis responded differently $(\mathrm{p}<0.05)$ among the three seeed sources based on the number of days taken for seeds to emerge. This could be as result of seed location or polymorphism phenomenon (Table 1). Mahgboub ${ }^{13}$ reiterated that polymorphism of $K$. senegalensis seed is one of the obstacles to uniform germination and successful plantation establishment. The period over which seed germination of $K$. senegalensis occured is in line with the study of Robertson and Reilly ${ }^{14}$ who reported that the germination in K. senegalensis seed

The result on fresh and dry weights indicated that seedlings treated with cow dung and Poultry manure had the highest mean fresh and dry weights among the three locations (Figures 2 and 3). The germination commenced after 10 to 14 days. The result also agrees with the study of Algunaid et al, who reported that the differences in $K$. senegalensis seed germination between zones may be attributed to the effect of environmental conditions and water availability in each zone ${ }^{11}$.

The effect of organic manure on the fresh weight of $K$. senegalensis seedlings may be due to the fact that the fertilizers have relatively higher amount of organic matter and nutrients than the other media. This is in line with the results of Uka et $a l^{15}$.., who recorded significantly higher mean fresh weight in plants treated with fertilizer than the unfertilized plants The higher performance of poultry manure may be due to its high organic matter content compared to the other treatments with respect to dry weight as indicated in the study of Swiader et $a l^{16}$.

Based on the treatments variation in leaf area of $K$. senegalensis seedlings, cow dung had the highest mean leaf area $(p<0.05)$ among the three seed sources (Table 2$)$. The highest mean leaf area was recorded in seedlings treated with organic fertilizers. This implies that organic manures have better enhanced growth performance of the seedlings compared to the inorganic fertilizer (NPK 15:15:15). This result agrees with the work of Ogunwale et $a l^{17}$, who asserted that the addition of organic matter content resulting from organic fertilizer application helps to improve nutrient availability to plants, especially in tropical soils that are generally low in soil organic matter.

The result on the number of leaves (Table 4) agrees with the study of Roger ${ }^{18}$, who reported that organic fertilizer steadily releases available nutrients over time and not like inorganic fertilizer which releases nutrients within a short period to plants. The result on poultry manure which showed the highest mean number of leaves in Oju may be attributed to higher concentration of nitrogen than in cow dung and inorganic fertilizer ${ }^{19}$. The result also confirms the findings of Swiader et $a l^{16}$., which reported that the best soil for growing seedlings is the one that is well drained and has a relatively high amount of organic matter ( 3 to $5 \%$ ).

The significant effect of fertilizer type on height growth implies that for healthy and fast growth of $K$. senegalensis seedlings in the study area, fertilizer type should be considered based on the source of the species 
seeds (Table 5). Application of organic and inorganic fertilizer responded differently $(\mathrm{p}<0.05)$ with regard to collar diameter of K. senegalensis seedlings among the three seed sources (Table 6). The result implies that there is no need to apply fertilizer to enhance collar diameter, if $K$. senegalensis seeds are sourced from Vandeikya due to the insignificant effect of fertilizer type on the collar diameter. If the species seeds are sourced from Makurdi or Oju, there is need for the choice of fertilizer type to enhance increased collar diameter (Table 6). The application of inorganic fertilizer on $K$. senegalensis seedlings had a negative effect on seedlings as many seedlings died. This could be due to high fertilizer dosage or toxicity. Thus, to minimize cost and the loss of Khaya senegalensis seedling at an early stage, there is need to reduce the rate of NPK 15:15:15 fertilizer application.

\section{Conclusion and Recommendations}

Seeds sourced from Makurdi recorded the highest germination percentage compared to seeds from Vandeikya and Oju. Germination rates were significantly different among the three seed sources (Vandeikya ,Makurdi and Oju) When raising $K$. senegalensis seedlings for plantation establishment, from the study locations, seeds sourceis vitaland should be consigered as an important factor Poultry manure proved better than cow dung manure and NPK fertilizer because it produced better growth attributes such as height, collar diameter fresh and dry weight. $K$. senegalensis can best be grown in nurseries in Benue State for successful plantation establishment with the application of poultry manure. For successful production of $K$. senegalensis seedlings, further research should be undertaken using lower rates of NPK fertilizer application so as to reduce seedling mortality

\section{Acknowledgement}

The approval granted by Dr E.T. Tembe, the Head, Department of Forest Production and Products, Federal University of Agriculture Makurdi, Nigeria, for carrying out this research in the Department's Forestry Nursery is highly appreciated.

\section{References}

1. Orwa C, A Mutua, Kindt R, Jamnadass R, S Anthony. 2009 Agroforestree Database:a tree reference and selection guide version 4.0 (http://www.worldagroforestry.org/sites/treedbs/treedatabases.asp)

2. Focho Derek Afa1, EnekeBechem, Egbe Andrew, Fongod Augustina Genla, Fonge Beatrice Ambo and Njoh Roland Ndah( 2011): Effects of organic and inorganic fertilizers on early growth characteristics of Khaya ivorensis Chev (African mahogany) in nursery. African Journal of Plant Science Vol. 5(12), pp. $722-729$

3. World Agroforestry Centre (2004): Khaya senegalensis;In:Agroforestry Database. $<$ http://www.world agroforestry. Org/Sites /TreeDBS /AFT/SpeciesInfo.m? SpID=1027.

4. Arnold, R. Reilly, D., Dickinson, D. and Jovannovic ,T. (2004) De Senegalensis for Plantations in Australia. Working Paper "Prospects for high-value Timber Plantations in Australia", Maceeba, Queensland, 1921October, 2004. Forestry North Queensland Association Inc., Kairi, Qeensland.

5. Kubmarawa, D., Khan, M. E., Punah, A. M. and Hassan, M. (2008). Phytochemical and Hassan, M. (2008). Phytochemical screening and antimicrobial efficacy of extracts of Khaya senegalensis against human pathogenic bacteria. African Journal of Biotechnology, 7(24): 4563-4566

6. Parray, B. A., Ganai, A. M. and Fazili, K. M. (2007). Physicochemical parameters and growth yield of tomato (Lycopersicum esculentum): Role of farm yard manure and neemcake. American-Eurasian Journal of Agricultural and Environmental Science, 2 (3): 303-307.

7. Seibert, U. (2007): "Languages of Benué State"; Nigerian Languages; Department of Languages and Linguistics, University of Jos

8. Imoro, A-W.M.; Sackey I. and Abubakari, A-H. (2012): Preliminary Study on the Effects of Two Different Sources of Organic Manure on the Growth Performance of Moringaoleifera Seedlings; Journal of Biology, Agriculture and Healthcare www.iiste.org ISSN 2224-3208 (Paper) ISSN 2225-093X (Online) Vol 2, No.10; pp: $147-158$.

9. Uka, U,N. Chukwuka, K.S. and Mary Iwuagwu,(2013) Relative effect of the application of organic and inorganic fertilizers on the growth of okra [Abelmoschus esculentus (1.) Moench] Journal of Agricultural Sciences 56(3) 159-166,

10. Aluko O.A.; Olanipekun T,O.; Olasoji J.O.; Abiola I.O.; Adeniyan O.N.; Olanipekun S.O.; Omenna E.C.; Kareem K.O. and Douglas A.I. (2014): effect of organic and inorganic fertilizer on the yield and nutrient composition of jute mallow; Global Journal of Agriculture Research Vol.2,No.3,pp.1-9; Published by European Centre for Research Training and Development UK (www.eajournals.org

11. Algunaid, F. H.; Ibrahim, A.M. and Zahran, B. B. (2013): Khaya senegalensis seeds polymorphism and dormancy breaking, Seeds collected from different localities in Sudan; International Journal of Scientific and Research Publications, Volume 3,ISSN 2250-3153; www.ijsrp.org

12. William J. Asante, Kwame Ochire-Boadu and Baatuuwie N. B. (2012): Initial growth response of Moringa oleifera seedlings to different soil amendments. African Journal of Agricultural Research Vol. 7(45), pp. 
6082-6086

13. Mahgoub, S. (2002): Studies of Physiological, Environmental and of some forest tree species. Ph.D. Thesis, United Kingdom.

14. Robertson B. and Reilly D. (2012): Growing African Mahogany in Northern Australia https://dpir.nt.gov.au/_data/assets/pdf_file/0005/233555/811.pdf . Assessed on 31/12/2018

15. Uka, U,N., Chukwuka,K.S. and Iwuagwu,M. (2013) Relative effect of the application of organic and inorganic fertilizers on the growth of okra [Abelmoschus esculentus (L) Moench] Journal of Agricultural Sciences 56(3) 159-166,

16. Swiader, M.J. Ware, W. and McCollum, J.P. (1992). Producing Vegetables Vero Media inc: 4th edition (Jan 19992). Pp 105.

17. Ogunwale, J.A; Olaniyan, J.O; and Aduloju, M.O. (2002). Morphological, Physio-chemical and cla mineralogical properties of soil overlaying basement complex rocks in llorin East, Nigeria. Moor J. Agric. Res. 3.2:147-154

18. Roger, A., (2004); Khaya senegalensis-current use from its natural range and its potential in Sri-Lanka and elsewhere in Asia. CSIRO and Forest Research, Kingston. ACT 2604.

19. Awodun, M. A., Osundare, O. T., Oyelekan, O. A. and Okonji, C. J. (2015): Comparative effects of organic and inorganic soil amendments on the growth of cashew nut (Anacardium occidentale I.) seedlings. Journal of Agricultural Biotechnology and Sustainable Development 7 (4) 37-42

\section{Biodata of Authors}

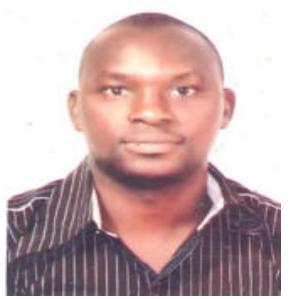

Emmanuel Dauda Kuje, is a Nigerian. He graduated with BSc. in Forestry from the Nassarawa State University and is terminally on a Master of Forestry Degree Programme in Forest Biology and Silviculture with the Department of Forest Production and Products, Federal University of Agriculture Makurdi, P.M.B. 2373, Nigeria

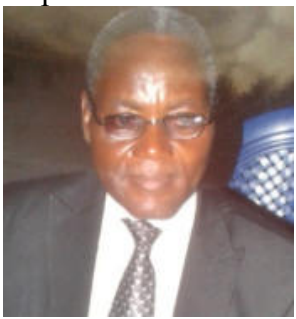

Dr. Stephen Iorliam Naishima Agera was born on 14/12/1956 in Benue State, Nigeria. He graduated from the University of Ibadan in 1979 with BSc. (Agric); in 2004, he obtained MSc. (Forest Resources Mgt) from the same University (Ibadan) In 2016, he graduated with a $\mathrm{PhD}$ in Forest Biology and Silviculture from the Federal University of Agriculture Makurdi. In 2006 he was employed by the Federal University of Agriculture Makurdi as lecturer II and is currently a Senior Lecturer in the Department of Forest Production and Products.. His research interests are: Silviculture, Agroforestry, Forest ecology and Environmental Forestry.

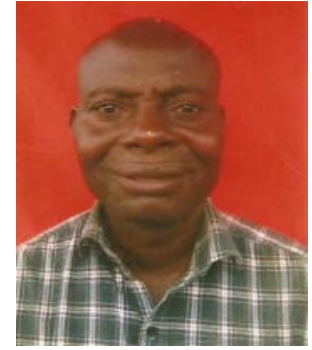

Dr. Joseph Igba Amonum graduated from the University of Jos, Nigeria with BSc in Botany. He completed his MSc. and PhD degrees in Forest Biology and Silviculture from the University of Ibadan, Nigeria and was employed in 2001 as an Assistant Lecturer by the Federal University of Agriculture Makurdi, Nigeria. He is currently an Associate Professor of Agroforestrry and Forest Ecology in the Department of Forest Production and Products, Federal University of Agriculture Makurdi, Nigeria. 